TEME, г. XLIII, бр. 2, април - јун 2019, стр. 557-577

Оригинални научни рад $\mathrm{https} / /$ doi.org/10.22190/TEME190131034M

Примљено: 31. 1. 2019.

UDK 378:37.017

Ревидирана верзија: 8. 4. 2019

Одобрено за штампу: 21. 6. 2019.

\title{
ASSESSMENT OF HIGHER EDUCATION SERVICE QUALITY: INTEGRATION OF SERVQUAL MODEL AND AHP METHOD
}

\author{
Radenko Milojević, Marija Radosavljević* \\ University of Niš, Faculty of Economics, Niš, Serbia \\ marija.andjelkovic@eknfak.ni.ac.rs
}

\begin{abstract}
In order to sustain or improve a position, higher education institutions have to realize that service quality is a critical condition for survival and growth in the education market. Therefore, the purpose of the research presented in this paper is to emphasize quality as a source of competitive advantage of higher education institutions, as well as to identify opportunities for improving service quality. The main objective of the research is to evaluate whether service quality determines students' satisfaction. The data provided by empirical research, conducted at universities in Serbia, have been subject to model that is usually used for service quality assessment and evaluation (SERVQUAL model). This model is valuable, but certainly not sufficient for creating an improvement map. Therefore, for identification of improvement priorities, in addition to SERVQUAL model, AHP method, pared t-test, ANOVA and regression analysis have been used. The results of the analysis indicate a gap between service quality that students expect and perceive. In addition, based on quantitative analysis, priorities for improvement of service quality are identified.
\end{abstract}

Key words: $\quad$ assessment, quality, higher education, SERVQUAL model, AHP method.

\section{ПРОЦЕНА КВАЛИТЕТА УСЛУГА \\ ВИСОКОГ ОБРАЗОВАҢА: ИНТЕГРАЦИЈА SERVQUАL МОДЕЛА И АНР МЕТОДА}

\section{Апстракт}

Да би задржале или побољшале позицију, високообразовне институције морају схватити да је квалитет услуга критичан услов за опстанак и раст на тржишту образовања. Сврха истраживања представљеног у овом раду јесте да се истакне квалитет као извор конкурентске предности високообразовних установа, као и да се идентификују могућности за побољшање квалитета услуга. Основни циљ истраживања је да се процени да ли квалитет услуге утиче на задовољство студената. Подаци добијени овим емпиријским истраживањем, спроведеним на универзитетима у Србији, били су предмет модела који се обично користи за 
процену и оцену квалитета услуга (SERVQUAL модел). Овај модел је користан, али сигурно није довољан за креирање мапе побољшања. Стога, за идентификацију приоритета побољшања, поред SERVQUAL модела, коришћен је АНР метод, упарени т-тест, ANOVA и регресиона анализа. Резултати анализе указују на присуство јаза између квалитета услуга који студенти очекују и перципирају. Поред тога, на основу квантитативне анализе идентификовани су приоритети за побољшање квалитета услуга.

Кључне речи: процена, квалитет, високо образовање, SERVQUAL модел, AHP метод.

\section{INTRODUCTION}

Educational systems and institutions that provide education services represent significant factors of society and economy development. Since changes in the environment happen on an everyday basis, educational institutions have to keep up with them. This is especially important for higher education institutions (HE institutions), such as universities, colleges, and faculties. During education process, people are acquiring and developing their knowledge, but also raising their competences, professional and social skills. Though all levels of education have purpose and a role in providing society development, the significance of higher education in the twenty first century has especially increased. In the same way that high school education was important a few decades ago higher education has become very important ingredient for a good job and comfortable lifestyle in the twenty first century (Immerwahr, 2002).

About two decades ago, HE institutions in developing countries face some challenges as a consequence of greater competition for resources, strong competition from new providers of higher education services (from private sector), and significantly reduced public funding. Also, challenges include new forms of learning, new technologies for teaching, and new competences of students. Against this background, it is evident that HE institutions have to carry out market research and keep a track on changes in the environment. Quality must not represent just one of the courses intended for students, but also a way for achieving and sustaining a competitive advantage, since the consequences of service quality are composed of trust, satisfaction, and image (Sultan, \& Yin Wong, 2012).

Measuring quality of HE institutions' services is an important task for providing feedback on the elements of quality that need to be taken care of and, therefore, represents the possibility to gain significant competitive advantage in knowledge market (Faganel, 2010). For this purpose, SERVQUAL model has earned great popularity and wide application in last decades (Khodayari \& Khodayari, 2011). In the first part of the paper the attention is on challenges of higher education institutions in developing countries and literature review concerning measuring service quality in $\mathrm{HE}$ institutions based on SERVQUAL model. The second part concerns the 
Methodology of the research and hypotheses development. The last part, beside the Conclusion sections, represents the Results and discussion section.

\section{CHALLENGES OF HIGHER EDUCATION INSTITUTIONS IN DEVELOPING COUNTRIES}

Expanding and strengthening the system of higher education represents a significant resource for developing countries in providing economic and social development and narrowing development gaps (Bloom \& Rosovsky, 2006). However, developing countries are disadvantaged significantly since the wealth of the nations has a great role in defining and determining the quality of a university or academic system (Rena, 2010). On the other hand, in developing countries higher education is more market exposed, compared to the other, lower levels of education. This occurs due to the fact that primary and high school education is mostly performed in state schools (private schools are rare and a privilege of a small number of people), and therefore it may be said that competition is very limited. In the last century, this was also the scenario for higher education. However, at the end of the twentieth and the beginning of the twenty first century private education providers appeared and caused an increase in competition in the higher education market.

Competition does not appear only inside the country (mostly between state and private universities), but also outside the country (universities worldwide), since the globalization trend does not exclude education. This means that the behaviour of HE institutions should be more market-like (Rhoades \& Slaughter, 2004) and that providers of services in higher education have to reconsider and reassess their role and position in the education system, as well as in the education market. Therefore, the first thing that should be reassessed at the HE institutions is service quality.

Difficulty of defining service quality cannot be denied, since it is greatly influenced by its subjective nature (Reisinger, 2001). However, it does not mean that quality of service should not be assessed and improved. In order to provide evidence and approval for implementing quality practice in education institutions, West, Noden and Gosling (2000) proposed a process view of the education system. Precisely, they observed education as a process similar to any process in industry and claimed that it may be observed as a network composed of inputs, transformation process and outputs. In accordance with that, they have classified quality attributes into three groups: inputs (raw materials), processes (procedures), and outputs (services). This classification represents a basis for implementing quality improvement tools and accepting quality management philosophy for improving quality of service in education. Other authors observe quality 
in higher education from a wider perspective, since beside quality of the service itself; they include passionate and experienced staff, an orderly school environment, ethical principles and other elements that affect attractiveness of the educational institution (Merwe, 2011). Still, other authors (Gibbs, 2004) observe quality in higher education in a very narrow way (through the quality of the courses offered by a university or a college) in order to highlight areas in which additional efforts should be taken for performance improvement.

In the case of higher education, the 'customers' are students who actually experience and perceive the service directly and therefore they represent the central stakeholder in higher education and the stakeholder that has an active role in the education process (Maassen, 2000; Ramsden, 2003). Besides students, the other group of stakeholders that may, and should, influence improving service quality are faculty members (professors and associates). Though students may know what kind of service they want to receive, faculty members are the ones that discover, create and develop knowledge, so they may offer services that students are not aware of, but they are important for developing their knowledge and skills. This means that students are the central stakeholder in higher education, and that faculty members are a kind of moderator, that should direct them towards useful and applicable knowledge and skills, in order ensure their satisfaction with the quality of service they receive. Concerning this, it is obvious that actions for service quality improvement have to be based on the students' expectations and perceptions (Red \& Johnston, 1999).

This further means that higher education institutions have to provide feedback about students' satisfaction (Rowley, 2003). One of the ways for providing feedback from students is to give them an opportunity to propose suggestions for improvement. The importance of students' satisfaction and improvement of education service quality has been confirmed by many authors (Banwet \& Datta, 2003; Spooren \& Mortelmans, 2006; McPherson, 2006; Smith \& Clarke, 2007; Segers, Gijbles, \& Thurlings, 2008; Yeo, 2008; Lee \& Tai, 2008; Weinberg, Hashimoto, \& Fleisher, 2009; Yousapronpaiboon, 2014).

However, if this feedback is not systematic, then the results of the improvements that have been introduced will not be measurable and comparable. Therefore, a better way for obtaining feedback from students is systematic research. The SERVQUAL method (Parasuraman, Zeithaml, \& Berry, 1985; Parasuraman, Zeithaml, \& Berry, 1988) is aimed precisely for organizations whose main output is service. This method may be used for assessment of students' satisfaction and evaluation of higher education service quality. It assumes evaluation of different elements of service quality: tangibility, reliability, responsiveness, assurance, and empathy (Hirmukhe, 2012). Tangibility (T) refers to physical facilities, equipment, personnel and communication material that are used in higher education 
institutions. Reliability (RE) may be explained as the ability to perform promised service dependably and accurately or to provide implementation of proposed curricula. Responsiveness (RS) represents willingness to help customers and provide prompt service, which means that faculty members are flexible and adoptable to meet students' needs. Assurance (A) means that service provider has professional competence (skills and knowledge) to perform the service, but also social competence (politeness, honesty) to work with students. Finally, empathy (E) means understanding students and providing access to the services according to their needs or providing a comfortable and friendly environment for students. SERVQUAL has been frequently used as the framework for service quality assessment (Babakus \& Boller, 1992; Sahney, Banwet, \& Karunes, 2004; Faganel, 2010).

The subsequent developments in service quality measures have followed the SERVQUAL methodology. One such development was the SERVPERF scale, also known as performance-only scale (Cronin and Taylor, 1992, 1994). The SERVPERF Service quality in higher education 261 scale is the un-weighted perception components of the SERVQUAL scale, which consists of 22 perception items and excludes any consideration of expectations. The performance-only construct, the SERVPERF, demonstrates its relative superiority over the SERVQUAL scale in terms of statistical analysis. Although the SERVPERF scale is based on customer scores evaluating perceived SERVPERF, it seems reasonable to assume that such judgments of customers are formulated with reference to some form of expectations. Expectations, regardless of whether they are measured explicitly or not, are likely to form an anchor for quality assessment (Devlin et al., 2002).

Some authors assessed service quality through models utilizing elements similar to those suggested by SERVQUAL model. For example, Hill, Lomas, and MacGregor (2003) thought that quality identification may be provided through focus groups. Some authors have suggested using the following elements for a survey questionnaire of service quality evaluation (Douglas, Douglas, \& Barnes, 2006): physical or facilitating goods, sensual service provided or the explicit service, and psychological service or the implicit service. Similarly, some authors (Whitty \& Power, 2000) suggest that quality of service in education may be assessed from two perspectives: extrinsically (location, size, facilities, and competences) and intrinsically (culture of learning and teaching). Advocating that SERVQUAL has some limitations regarding applicability, Zafiropoulos and Vrana (2008) suggest that it still may be used as a complementary research instrument for assessing service quality. Therefore, for the purpose of researching service quality in higher education, the SERVQUAL model seems acceptable and usable.

Significance of higher education quality in the Republic of Serbia has been topic of few research papers. In one of the papers authors (Milutinović 
\& Nikolić, 2014) emphasise the significance of improving education system quality and efficiency for sustainable economic development. They also point out the results presented at the UNESCO 2009 World conference on higher education, where the Republic of Serbia has been classified as typical peripheral developing country regarding higher education, thus indication the decrease of teaching and learning quality. Some authors (Popović, Stanković $\&$ Đukić, 2015) suggest that people responsible for managing the activities of higher education institutions should conduct a systematic research to detect the factors on the basis of which students choose the institution and study program. The main aim of one study was to examine the relationship between service quality and customer satisfaction and their impact on behavioural intentions in higher education setting in Serbia (Dado, et al, 2012). Although there is some evidence on HE institutions' service quality, there is no research that would provide the evidence about the influence of service quality elements on students' satisfaction, as well as the evidence about the most important service quality elements from students' point of view.

\section{METHODOLOGY OF THE RESEARCH}

In this research focus is on HE institutions in the Republic of Serbia, as the developing countries. During the last decade or more, after initiating the practice based on Bologna Declaration and the appearance of a few private universities, the situation in the education market has been changed. In this context, students' evaluation of higher education service quality is very important for every higher education institution (Isely \& Singh, 2005).

To the best knowledge of the authors, research based on the SERVQUAL model, in this research area, has not been conducted in Serbia, so far. Research results concerning quality of service in higher education do not exist or at least are not available. It seems that the role of quality tools for the improvement of higher education service in Serbia is underestimated or, at least, it is not used to full capacity, since there is no comprehensive research study that would indicate directions for quality improvement. Considering that, the research results presented in this paper represent an attempt for pointing out the need for changes at the HE institutions in developing countries, and just one step towards further, deeper analysis of higher education service quality. 


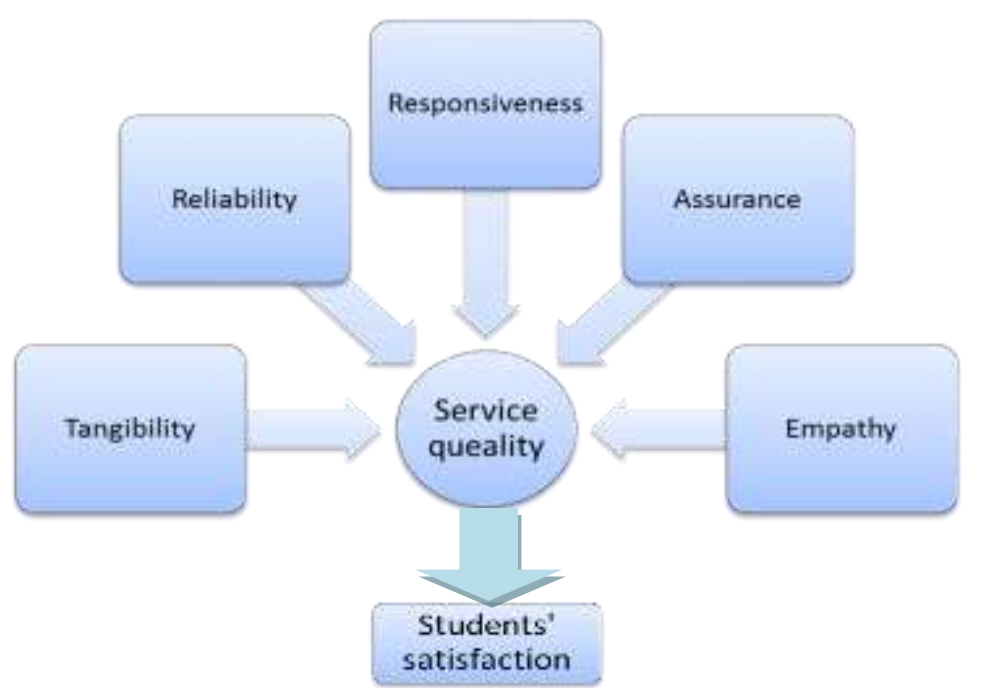

Figure 1. The research framework

The purpose of this research is identification of the opportunities for improving service quality in HE institutions. Therefore, the main objective is to evaluate whether and how service quality determines students' satisfaction. The main task of the research is discovering critical requirements for providing students' satisfaction, in terms of service quality elements. Consequently, the results should be useful for making decisions in order to provide decreasing of the gap between the quality level that students' expect and the quality level that they currently perceive. In order to achieve the objective of the research the following hypotheses will be tested:

H1: Service elements are not equally important for providing students' satisfaction,

H2: There is gap between expected and perceived level of HE service quality,

H3: There is statistically significant difference of perceived level of service quality elements' (tangibility, reliability, responsiveness, assurance, and empathy),

H4: The impact of service quality on students' satisfaction is statistically significant.

The questionnaire used in this research is based on a standard SERVQUAL questionnaire, with a few adaptations for the purpose of the research and the context (Appendix 1). During structuring of this questionnaire, Rules of standards for self-evaluation and quality assessment of higher education institutions (http://www.mpn.gov.rs), were considered, too. Beside standard 22 questions, the questionnaire included general data concerning year of study and sex, but also two very important questions: 
- First concerns the students' general satisfaction with the service quality (measured, also, on the seven-point Liker scale) and

- Second concerns the relative importance of service quality elements (comparing one to another).

The research has been conducted within the population of students at the universities in Serbia. Bearing in mind that private universities have been created recently (the most of them less than 5 years ago, some existed only in certain period of time) and some faculties they consist of are still in the process of accreditation, in this research were included only students attending state universities. The questionnaire has been sent to 1000 students, but 662 questionnaires have been completed, which means that the rate of response is $66.2 \%$. The questionnaire includes five sets of items, for each element of service quality. The total number of items under five elements is 22 (Parasuraman, Berry, \& Zeithaml, 1991). Items have been evaluated by using a Likert scale (7-point), where 1 means that student strongly disagrees and 7 that she/he strongly agrees. The interviewees have evaluated given items from two perspectives: expectations and perceptions. Evaluation of items from the expectations perspective shows which service elements are most important or even critical for providing satisfaction of students. On the other hand, evaluation of items from the perceptions perspective indicates the students' satisfaction with the specific service (Parasuraman, Berry, \& Zeithaml, 1991), in this case the service of the state universities.

\section{RESULTS AND DISCUSSION}

In order to approve reliability of the data collected, Cronbach's Alpha test (Zafiropoulos \& Vrana, 2008) has been used. Cronbach's Alpha is a measure of internal consistency. Its value depends on average inter-item correlation. If average inter-item correlation is low, Cronbach's alpha will be low, too. When Cronbach's Alpha is higher than 0.70 the reliability is considered acceptable in social science research situations (Trochim 2001), though there is an opinion that Alpha value higher than 0.50 is acceptable, too (Cohen, Manion, \& Morrison, 2008). For 22 elements (items) included in the SERVQUAL model Cronbach's Alpha is equal 0.938 for expectations and 0.927 for perceptions, suggesting that the items have high internal consistency (Cronbach's Alpha for individual claims or questions is presented in the Appendix 2a and 2b). The average value of Cronbach's Alpha is an indicator of internal consistency, but beside this average value it is useful to calculate Cronbach's Alpha for individual items, in case the item is deleted. Those individual Alphas should be compared to the average Cronbach's Alpha value. If individual Alphas are lower than the average value then internal consistency has been confirmed. If any individual Alpha has higher value, compared to 
the average, the item should be excluded from further analysis since it makes other items less consistent. In this case Cronbach's Alphas for individual items are lower than the average value (but still higher than 0.70) for all items except ERE3 and EE3 (for expectations), as well as except PRE3 and PRS1 (for perceptions). After excluding those items from the analysis, internal consistency is provided.

Since internal consistency is confirmed, the data may be used for further analysis. In order to get insight into some basic indicators, descriptive statistics has been used (Table 1). The first impression is that the same service element got the highest average value, for expectations, as well as for perceptions. This element is Reliability. Comparison of the expected and perceived average value for this service element is can be seen that perceived value is higher than expected. This positive difference may be observed as good result.

Table 1. Descriptive Statistics

\begin{tabular}{lccccc}
\hline & $\mathrm{N}$ & Minimum & Maximum & Mean & $\begin{array}{c}\text { Std. } \\
\text { Deviation }\end{array}$ \\
\hline aveET & & & & & 1.14575 \\
aveERE & 662 & 1.50 & 6.75 & 4.7651 & 1.14496 \\
aveERS & 662 & 1.50 & 6.50 & $\mathbf{4 . 8 3 5 0}$ & 1.90576 \\
aveEA & 662 & 1.50 & 6.00 & 3.9071 & .97603 \\
aveEE & 662 & 2.25 & 6.75 & 4.5906 & .97603 \\
avePT & 662 & 1.25 & 6.50 & 3.3705 & .91411 \\
avePRE & 662 & 2.25 & 7.00 & 3.7171 & 1.22550 \\
avePRS & 662 & 2.25 & 7.00 & $\mathbf{5 . 6 8 5 0}$ & 1.02583 \\
avePA & 662 & 2.33 & 7.00 & 5.4048 & .95868 \\
avePE & 662 & 1.50 & 6.00 & 2.9551 & 1.11106 \\
\hline SATISF & 662 & 2.40 & 6.80 & 4.4861 & .82994 \\
\hline
\end{tabular}

However, usually not all service elements are equally important from the the students' perspective. This importance of service elements actually influences the weight coefficients necessary for performing SERVQUAL analysis. Weight coefficients calculation should provide data for testing the first hypothesis (H1: Service elements are not equally important for providing students' satisfaction).

Therefore, in order to provide more accurate results, for the total gap calculation it is suggested to use AHP model (as supporting tool) in

\footnotetext{
* The meaning of the symbols is given in the Appendix 1, prefix "ave" refers to average value for each variable, based on items it includes, prefix "E" refers to expected values, while prefix " $P$ " refers to perceived values of the variables and items they consist of. Variable SATISF represents student's satisfaction and it represents the only variable in the model.
} 
order to determine the weight coefficients (Importance weight). The AHP method was created by the mathematician Thomas Lorie Saaty (Wagner et al, 2018). It consists of an analytical method that seeks for a systematic approach to solve a highlighted objective (Saaty, 1986). For this purpose, authors used the data about the relative importance of the service quality elements and usual procedure in AHP method. Pair-wise comparisons were made based on the relative importance of service quality elements, from the interviewed students' perspective (Table 2).

Numbers in the Table 2 show relative importance between the observed service quality elements. For example, number 4 in the second row, shows that the relative importance of the row variable Reliability compared to the column variable Tangibility is higher and, precisely, 4 means that the students thing that it is between moderately and strongly more important. If the number in the Table 2 is lower than 1, it means that the column variable is considered more important than the row variable. For example, the number 0.5 in the first row shows that the variable Responsiveness is considered two times more important compared to the Tangibility.

Table 2. Pair-wise comparisons

\begin{tabular}{lrrrrr}
\hline & T & RE & RS & A & \multicolumn{1}{c}{ E } \\
\hline T & 1 & 0.25 & 0.5 & 0.5 & 0.25 \\
RE & 4 & 1 & 1.33 & 2 & 1 \\
RS & 2 & 0.75 & 1 & 1 & 0.75 \\
A & 2 & 0.5 & 1 & 1 & 0.5 \\
E & 4 & 1 & 1.33 & 2 & 1 \\
Sum & 13 & 3.5 & 5.16 & 6.5 & 3.5 \\
\hline
\end{tabular}

Table 3 includes the corresponding numbers from Pair-wise comparisons divided by the sum of the appropriate columns. Column Weight represents the average value for the corresponding row, presented in percentage form. By observing data from the column Weigh it can be said that the first hypothesis should be accepted or that service elements are not equally important for providing students' satisfaction. The two most important service quality elements, with the same importance weight, are Reliability and Empathy.

Table 3. Standardized matrix

\begin{tabular}{lcccccr}
\hline & $\mathrm{T}$ & $\mathrm{RE}$ & $\mathrm{RS}$ & $\mathrm{A}$ & $\mathrm{E}$ & Weight \\
\hline $\mathrm{T}$ & 0.076923 & 0.071429 & 0.096774 & 0.076923 & 0.071429 & $\mathbf{7 . 8 7 \%}$ \\
$\mathrm{RE}$ & 0.307692 & 0.285714 & 0.258065 & 0.307692 & 0.285714 & $\mathbf{2 8 . 9 0 \%}$ \\
$\mathrm{RS}$ & 0.153846 & 0.214286 & 0.193548 & 0.153846 & 0.214286 & $\mathbf{1 8 . 6 0 \%}$ \\
$\mathrm{A}$ & 0.153846 & 0.142857 & 0.193548 & 0.153846 & 0.142857 & $\mathbf{1 5 . 7 4 \%}$ \\
$\mathrm{E}$ & 0.307692 & 0.285714 & 0.258065 & 0.307692 & 0.285714 & $\mathbf{2 8 . 9 0 \%}$ \\
\hline
\end{tabular}


In order to check whether the data may be used for further analysis, it is necessary to calculate Consistency index. Consistency index has been calculated in the Excel, based on the MMULT function (the matrix multiplication function). This function multiplies rows from Table 2 and column Weight from Table 3. For calculating Consistency, MMUL has been divided by the column Wight. Number of comparisons represents the number of variables observed and compared. Consistency index (CI) is calculated as the quotient of dedication between Average consistency and Number of comparisons, on one side, and Number of comparisons dedicated by 1 , on the other side. When CI is lower than 0.01 it can be said that the observed data are consistent and thus reliable for usage in further analysis. According to the data from Table $4, \mathrm{CI}$ is 0.0066 , so previously determined weight for service elements can be used for further analysis.

Table 4. Consistency index calculation

\begin{tabular}{lcc}
\hline & MMULT & Consistency \\
$\mathrm{T}$ & 0.394859979 & 5.017567568 \\
$\mathrm{RE}$ & 1.455464965 & 5.036637226 \\
$\mathrm{RS}$ & 0.934207728 & 5.023637057 \\
$\mathrm{~A}$ & 0.789719957 & 5.017567568 \\
$\mathrm{E}$ & 1.455464965 & 5.036637226 \\
sum & 25.13204664 \\
\hline No of comparisons & \multicolumn{2}{c}{$\mathbf{5}$} \\
Average consistency & $\mathbf{5 . 0 2 6 4 0 9 3 2 9}$ \\
CI & $\mathbf{0 . 0 0 6 6 0 2 3 3 2 < 0 . 0 1}$ \\
\hline
\end{tabular}

Further analysis is based on SERVQUAL model. Analysis based on the SERVQUAL model actually includes gap calculation. Gap represents the difference between expected and perceived level of service quality. It can be calculated for every item given under five elements of service quality. At the level of the element, gap is calculated as the average score of gaps for each of its items (the gap for all items, four or five, depending on the element, is totalled and divided by the number of items under that specific element). When the same procedure is repeated for all five elements, an average SERVQUAL score may be determined (the gap score for five elements is totalled and divided by five). The number calculated in this way does not have specific meaning, besides the fact that its decreasing during the time indicates improvement of service quality.

Table 5 shows that there is a difference between expected and perceived level of quality for all service elements. The good thing is the fact that these differences in four out of five elements are positive, in favour of the education institutions. The information that proceeds from the SERVQUAL model implies that the second hypothesis is confirmed since there is a gap between expected and perceived levels of service quality. 
Table 5. SERVQUAL model results

\begin{tabular}{|c|c|c|c|c|c|}
\hline $\begin{array}{l}\text { Service } \\
\text { elements }\end{array}$ & $\begin{array}{c}\text { Expectations } \\
(\mathrm{E})\end{array}$ & $\begin{array}{l}\text { Perceptions } \\
\text { (P) }\end{array}$ & P-E & $\begin{array}{c}\text { Importance } \\
\text { Weight }\end{array}$ & $\begin{array}{l}\text { Weighted } \\
\text { Score }\end{array}$ \\
\hline $\mathrm{T}$ & 4.765106 & 3.717145 & -1.047960 & $7.87 \%$ & -8.24745 \\
\hline RE & 4.834970 & 5.685045 & 0.850076 & $28.90 \%$ & 24.56718 \\
\hline $\mathrm{RS}$ & 3.907100 & 5.404758 & 1.497659 & $18.60 \%$ & 27.85645 \\
\hline A & 4.590634 & 2.955060 & -1.635570 & $15.74 \%$ & -25.7439 \\
\hline E & 3.370468 & 4.486103 & 1.115634 & $28.90 \%$ & 32.24184 \\
\hline \multirow[t]{2}{*}{ Total } & & & & & 50.67408 \\
\hline & & ge n & IEA SEK V & core & 10.13482 \\
\hline
\end{tabular}

The positive difference exists for the Reliability, Responsiveness and Empathy, which may be considered as satisfying result, bearing in mind that those are exactly the elements whose Importance weight is the highest in comparison with other elements. The results of the SERVQUAL model are also presented in Figure 1. Since y-axis represents perceptions, the greatest attention should be paid to the service elements that have the lowest position, concerning perceived values. In this case those elements are Assurance and Tangibility. These service elements have the lowest average value (Assurance 2.9551 and Tangibility 3.7171).

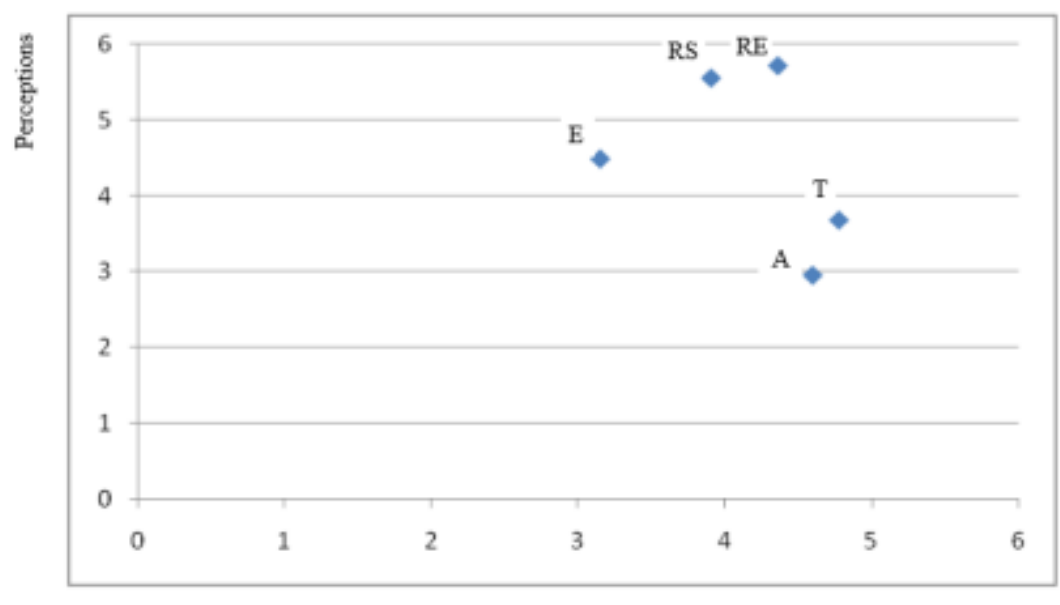

Expectations

Figure 1. Service elements position according to the SERVQUAL model results

Since the results are based on the sample it is useful to check whether the differences between the expectations and perceptions concerning service elements are statistically significant. For this purpose, pared t-test has been used (Table 6). Since significance (the data from the last column) is less than 
0.001 for all observed pairs (average expected and perceived values for each service element), it can be concluded that there is statistically significant difference between the expectations and perceptions for each of service quality variables, which confirm the gap existence. This is the confirmation of the conclusion made by the SERVQUAL model analysis or confirmation of the second hypothesis.

Table 6. Paired Samples Test

\begin{tabular}{|c|c|c|c|c|c|c|c|}
\hline & \multicolumn{4}{|c|}{ Paired Differences } & \multirow{3}{*}{$\mathrm{t}$} & \multirow{3}{*}{ df } & \multirow{3}{*}{$\begin{array}{c}\text { Sig. } \\
\text { (2-tailed) }\end{array}$} \\
\hline & \multirow[t]{2}{*}{ Mean $S$} & \multirow[t]{2}{*}{ Std. Dev. } & \multicolumn{2}{|c|}{$\begin{array}{c}\text { 95\% Confidence } \\
\text { Interval of the } \\
\text { Difference } \\
\end{array}$} & & & \\
\hline & & & Lower & Upper & & & \\
\hline Pair 1 aveET - avePT & 1.04796 & 1.45685 .05662 & .93678 & 1.15914 & 18.508 & 661 & .000 \\
\hline Pair 2 aveERE - avePRE & -.85008 & .62875 .02444 & -.89806 & -.80209 & -34.787 & 661 & .000 \\
\hline Pair 3 aveERS - avePRS & -1.4977 & .53401 .02075 & -1.53849 & -1.45698 & -72.163 & 661 & .000 \\
\hline Pair 4 aveEA - avePA & 1.63557 & .80505 .03129 & 1.57414 & 1.69701 & 52.273 & 661 & .000 \\
\hline Pair 5 aveEE - avePE & -1.1156 & .53720.02088 & $-1.15663-$ & -1.07464 & -53.433 & 661 & .000 \\
\hline
\end{tabular}

After the analysis has shown that there is statistically significant difference between perceptions and expectations, it is considered useful to test whether there is difference between five observed elements (when it is about students' perceptions). For this purpose the ANOVA test has been used (Table 7). A significance level of 0.05 or less indicates statistically significant differences among the means. The significance level in this case is less than 0.001, which means that there is a difference between perceived level of quality for service elements. Since the ANOVA test has shown that students' are not equally (dis)satisfied with all service elements, it can be said that the third hypotheses has been confirmed and that there is statistically significant difference of perceived level of service quality elements'.

Table 7. ANOVA results

\begin{tabular}{lrrrrr}
\hline & Sum of Squares & df & Mean Square & F & Sig. \\
\hline Between Groups & 3449.197 & 4 & 862.299 & 798.945 & .000 \\
Within Groups & 3567.077 & 3305 & 1.079 & & \\
\hline Total & 7016.275 & 3309 & & & \\
\hline
\end{tabular}

Since the universities cannot provide all necessary improvements at the same time, it may be useful to identify the items which have the greatest influence on students' satisfaction. Regression analysis has been used for this purpose, since it is usually used to answer the question "Which of the independent variables have greater effect on the dependent variable"? (Christensen, 1996). In this case service elements represent 
independent variables, while students' satisfaction represents dependent variable (Table 8). According to the results from Table 8 , it can be concluded that statistically significant impact on students' satisfaction exists only for fours variables - service elements, and they are Tangibility, Reliability, Responsiveness and Empathy.

Table 8. Regression analysis results

\begin{tabular}{|c|c|c|c|c|c|}
\hline \multirow[t]{2}{*}{$\begin{array}{l}\text { Individual claims } \\
\text { / questions }\end{array}$} & \multicolumn{2}{|c|}{$\begin{array}{l}\text { Unstandardized } \\
\text { Coefficients }\end{array}$} & \multirow{2}{*}{$\begin{array}{c}\text { Standardized } \\
\text { Coefficients } \\
\text { Beta } \\
\end{array}$} & \multirow[t]{2}{*}{$\mathrm{t}$} & \multirow[t]{2}{*}{ Sig. } \\
\hline & Beta & Std. Error & & & \\
\hline avePT & .396 & .059 & .399 & 6.723 & .000 \\
\hline avePRE & .348 & .052 & .350 & 6.720 & .000 \\
\hline avePRS & .803 & .060 & .639 & 13.284 & .000 \\
\hline avePA & .011 & .041 & .010 & .274 & .784 \\
\hline avePE & .170 & .042 & .137 & 4.022 & .000 \\
\hline
\end{tabular}

Dependent variable: Students' satisfaction

In addition, unstandardized Beta coefficients are positive, which means that independent variables have positive impact on the dependent one, or that increase of independent variables will lead to the increase of dependent variable. This result partly confirms the fourth hypothesis, so it may be said that the impact of service quality on students' satisfaction is statistically significant. According to standardized Beta coefficients, it may be concluded that the greatest impact on prediction of students' satisfaction, has Responsibility $(0.639)$, followed by Tangibility $(0,399)$ and Reliability (0.350).

For every service element, items with the highest Beta level should represent the priorities for the improvement of service quality according to students' perceptions. In order to more detail insight about the individual items (four or five claims or questions for each service element) impact on students' satisfaction, regression analysis can be performed at the claim level. In this case individual items represent independent variables, while students' satisfaction represents dependent variable.

\section{CONCLUDING REMARKS AND LIMITATIONS OF THE RESEARCH}

Universities in the developing countries have to confront quality level of the service they provide with the quality level that students' expect and perceive, since it is the greatest challenge they have to win in order to survive in very dynamic and flexible higher education marketplace. Analysis based on the SERVQUAL model shows that there is a gap between the quality level that students expect and the quality level they perceive. The positive gap may be considered as a consequence of the implementation of Bologna process, since some results from about 10 years ago, did not have the same, positive sign. 
Comparison of the results of this research with the results conducted by some other authors show more or less, similar situation. According to Wagner and its co-authors (2018) negative gap exists for some items under the elements Tangibility, Responsibility and Assurance. Exactly the same conclusion proceeded from Yousapronpaiboon's (2014) research. Similar are results presented by Chua (2004), which indicate negative difference for all five quality elements, but the greatest gap for Tangibility and Assurance. According to De Oliveira i Ferreira (2009, May) the most significant gap may be identified when it is about Tangibility. In case of this research, negative gap exist for Tangibility and Assurance.

Therefore, according to the research presented in this paper, Tangibility and Assurance are the "problematic" elements of the service quality. Therefore, HE institutions should pay more attention to these two elements. Considering the fact that, calculated based on AHP method, Assurance as service element has greater weight coefficient, this should be the first one for making the improvements. On the other side, Reliability and Empathy, which have the greatest weight coefficients, are at the same time the elements with significant positive gap, so they represent bright side of the HE institutions service quality. Finally, the best thing is the fact that regression analysis indicates statistically significant impact of all service elements for which positive gap has been identified, and also no statistically significant impact of Assurance, which characterizes negative gap. Therefore, it may be concluded that state universities are aware of students' expectations and provide service with positive perceptions.

The main limitation of this research concerns impossibility for comparison with the results of some other authors in the Republic of Serbia, in order to provide the evidence of the improvements in HE service quality. Regardless the fact that the students are the most important stakeholder in the education system, one of the limitations of this research certainly concerns the faculty members' point of view. Therefore, further research may include faculty members' perspective, too, which will be a starting point for identification of another gap - gap between the faculty members' opinion and students' wishes. Finally, for using these results for creating an improvement plan, Quality Function Deployment should be included into analysis.

\section{REFERENCES}

Babakus, E., \& Boller, G. W. (1992). An empirical assessment of the SERVQUAL scale. Journal of Business Research, 24, 253-268.

Banwet, D. K., \& Datta, B. (2003). A study of the effect of perceived lecture quality on post-lecture intentions. Work Study, 52(5), 234-243.

Bloom, E. E., \& Rosovsky, H. (2006). Higher Education in Developing Countries. International Handbook of Higher Education, 18, 443-459.

Christensen, R. (1996). Analysis of Variance Design and Regression - Applied statistical methods. London: Chapman \& Hall. 
Chua, C. (2004, July). Perception of quality in higher education. In Proceedings of the Australian universities quality forum (pp. 181-187). Australian University Quality Agency Melbourne.

Cohen, L., Manion, L., \& Morrison, K. (2005). Research methods in education. New York: Routledge.

Dado, J., Taborecka-Petrovicova, J., Cuzovic, S., \& Rajic, T. (2012). An empirical examination of the relationships between service quality, satisfaction and behavioral intentions in higher education setting. Serbian Journal of Management, 7(2), 203-218.

De Oliveira, O. J., \& Ferreira, E. C. (2009). Adaptation and application of the SERVQUAL scale in higher education. In Proceedings of POMS 20th Annual Conference Orlando, Florida USA.

Douglas, J., Douglas, A., \& Barnes, B. (2006). Measuring student satisfaction at a UK university. Quality Assurance in Education, 14(3), 251-267.

Faganel, A. (2010). Quality perception gap inside the higher education institution. International Journal of Academic Research, 2(1), 213-215.

Gibbs, V. (2004). A study of consumer expectations and perceptions in undergraduate higher education. Journal of Diagnostic Radiography and Imaging 5(2), 69-78.

Hill, Y., Lomas, L., \& MacGregor, J. (2003). Students' perceptions of quality in higher education. Quality Assurance in Education, 11(1), 15-20.

Hirmukhe, J. (2012). Measuring internal customers' perception on service quality using SERVQUAL in administrative service. International Journal of Scientific and Research Publications, 2(3), 1-6. Retrieved from www.ijsrp.org

Immerwahr, J. (2002). The Affordability of Higher Education: A Review of Recent Survey Research. San Jose, CA: The National Center for Public Policy and Higher Education. Retrieved from www.highereducation.org

Isley, P., \& Singh, H. (2005). Do higher grades lead to favourable student evaluations? Journal of Economic Education, 36(1), 29-42.

Khodayari, F., \& Khodayari, B. (2011). Service quality in higher education. interdisciplinary Journal of Research in Business, 1(9), 38-46.

Lee, J.-W., \& Tai, S. W. (2008). Critical factors affecting customer satisfaction and higher education in Kazakhstan. International Journal of Management in Education, 2(1), $46-59$.

Maassen, P. (2000). Editorial. European Journal of Education, 35(4), 377-383.

McPherson, M. (2006). Determinants of How Students Evaluate Teachers. The Journal of Economic Education, 37(1), 3-20.

Merwe, H. V. D. (2011). Migration patterns in rural schools in South Africa: Moving away from poor quality education. Education as Change, 15(1), 107-120

Milutinović, S., \& Nikolić, V. (2014). Rethinking higher education for sustainable development in Serbia: an assessment of Copernicus charter principles in current higher education practices. Journal of cleaner production, 62, 107-113.

Rulebook on standards and procedure for accreditation of higher education institutions and study programs, National Council for Higher Education Available at: http://www.mpn.gov.rs/wp-content/uploads/2015/09/ Pravilnik-za-akreditaciju.pdf

Parasuraman A, Zeithaml, V. A., Berry, L. L. (1985). A Conceptual Model of Service Quality and its Implications for Future Research. Journal of Marketing, 49(4), 41-50.

Parasuraman A, Zeithaml, V. A., Berry, L. L. (1988). SERVQUAL, A multiple item scale for measuring Perceptions of Service Quality. Journal of Retailing, 64(1), 12-40.

Parasuraman A, Berry., L. L., \& Zeithaml, V. A. (1991). Refinement and reassessment of the SERVQUAL scale. Journal of Retailing, 67(4), 420-450. 
Popović, A., Stanković, L., \& Đukić, S. (2015). Positioning Strategies of Higher Education Institutions in the Republic of Serbia. TEME: Casopis za Društvene Nauke, 39(3), 643-659.

Ramsden, P. (2003). Learning to Lead in Higher Education (2nd ed.). New York: Routledge.

Reid, D. J., \& Johnston, M. (1999). Improving Teaching in Higher Education: Student and teacher perspectives. Educational Studies, 25(3), 269-281.

Rena, R. (2010). Emerging trends of higher education in developing countries. Analele Stiintifice ale Universitatii Alexandru Ioan Cuza din Iasi, seria Stiinte Economice, Numar special: 301-315.

Rhoades, G., \& Slaughter, S. (2004). Academic capitalism in the new economy: Challenges and choices. American Academic, 1(1), 37-59.

Rowley, J. (2003). Designing student feedback questionnaires. Quality Assurance in Education, 11(3), 142-149.

Saaty, T. L. (1986). Axiomatic foundation of the analytic hierarchy process. Management science, 32(7), 841-855.

Sahney, S., Banwet, D. K., \& Karunes, S. (2004). A SERVQUAL and QFD approach to total quality education: a student perspective. International Journal of Productivity and Performance Management, 53(2), 143-166.

Segers, M., D. Gijbels, and M. Thurlings. 2008. The relationship between students' perceptions of portfolio assessment practice and their approaches to learning. Educational Studies, 34(1):35-44.

Smith, G. A., \& Clarke, A. (2007). Evaluating service quality in universities: a service department perspective. Quality Assurance in Education, 15(3), 334-351.

Spooren, P., \& Mortelmans, D. (2006). Teacher professionalism and student evaluation of teaching: will better teachers receive higher ratings and will better students give higher ratings? Educational Studies, 32(2), 201-214.

Sultan, P., \& Yin Wong, H. (2012). Service quality in a higher education context: an integrated model. Asia Pacific Journal of Marketing and Logistics, 24(5), 755-784.

Sultan, P., \& Yin Wong, H. (2010). Service quality in higher education-a review and research agenda. International Journal of Quality and Service Sciences, 2(2), 259-272.

Trochim, W. M., \& Donnelly, J. P. (2006). The Research Methods Knowledge Base. (3rd ed.). Mason, $\mathrm{OH}$ : Thomson Custom Publishing.

Wagner, A., Merino, E. A. D., Martinelli, M., Polacinski, É., da Silva Wegner, R., \& Godoy, L. P. (2018). The quality of services in a higher education institution: an evaluation for the integration of AHP, SERVQUAl and QFD methods. Disciplinarum Scientia| Sociais Aplicadas, 13(1), 109-130.

Weinberg, B., Hashimoto, M., \& Fleisher, B. (2009). Evaluating Teaching in Higher Education. The Journal of Economic Education, 40(3), 227-261.

West, A., Noden, P., \& Gosling, R. (2000). Quality in higher education: An international perspective. The views of transnational corporations. Market Papers, 17, London School of Economics and Political Science. doi: citeseerx.ist.psu.edu/ viewdoc/download? doi=10.1.1.110.7633.pdf.

Whitty, G., \& Power, S. (2000). Marketization and privatization in mass education systems. International Journal of Educational Development, 20, 93-107.

Yeo, R. K. (2008). Brewing service quality in higher education. Quality Assurance in Education, 16(3), 266-286.

Yousapronpaiboon, K. (2014). SERVQUAL: Measuring higher education service quality in Thailand. Procedia-Social and Behavioral Sciences, 116, 1088-1095.

Zafiropoulos, C., \& Vrana, V. (2008). Service quality assessment in a Greek higher education institute. Journal of Business Economics and Management, 9(1), 33-45. 
Appendix 1. Questionnaire for the assessment of students' expectations and perceptions

\author{
Tangibility \\ The appearance of the school physical facilities, equipment, personnel, and \\ communication materials. \\ T1: School is equipped with modern technology. \\ T2: School has adequate books and other materials for exams preparation. \\ T3: School has appropriate classrooms for delivering lectures. \\ T4: School's communication channels are clear and helpful.
}

\author{
Reliability \\ Faculty members' ability to perform the promised services dependably and \\ accurately. \\ RE5: Faculty members have knowledge and skills in accordance to course content. \\ RE6: Faculty members have knowledge and skills to respond to students' needs. \\ RE7: Faculty members have knowledge and skills to perform educational services (learning \\ methods). \\ RE8: Faculty members fulfil commitments given to students. \\ RE9: Faculty members' information is error free.
}

\title{
Responsiveness \\ Faculty members' willingness to help students and provide prompt service.
}

RS10: Faculty members tell exactly when they are able to respond to a request.

RS11: Faculty members give a prompt service.

RS12: Faculty members are always willing to help.

RS13: Faculty members have convenient working (office) hours.

\section{Assurance}

Knowledge and courtesy of faculty members and their ability to convey trust and confidence.

A14: Behaviour of faculty members instils confidence in students.

A15: Faculty members keep given promises.

A16: Faculty members are always polite.

A17: Rules and regulations in school are transparent.

\section{Empathy}

Faculty members try to provide a caring and individualized attention to students.

E18: Faculty members respond to students' questions patiently.

E19: Faculty members create peaceful environment.

E20: Faculty members respect feedback from students.

E21: Faculty members take care to understand students' requests.

E22: Faculty members are flexible and willing to communicate with students beyond office hours. 
Apendix 2a. Cronbach's Alpha for service elements for expectations.

\begin{tabular}{|c|c|c|c|c|}
\hline \multicolumn{2}{|c|}{ Cronbach's Alpha } & $\mathrm{N}$ of Items & & \\
\hline \multicolumn{2}{|c|}{.938} & 22 & & \\
\hline \multicolumn{2}{|r|}{$\begin{array}{l}\text { Scale Mean if } \\
\text { Item Deleted }\end{array}$} & $\begin{array}{l}\text { Scale Variance } \\
\text { if Item Deleted }\end{array}$ & $\begin{array}{c}\text { Corrected Item- } \\
\text { Total } \\
\text { Correlation } \\
\end{array}$ & $\begin{array}{c}\text { Cronbach's } \\
\text { Alpha if Item } \\
\text { Deleted } \\
\end{array}$ \\
\hline ET1 & 81.0876 & 261.060 & .689 & .934 \\
\hline ET2 & 81.8066 & 263.261 & .597 & .936 \\
\hline ET3 & 80.8021 & 257.082 & .815 & .931 \\
\hline ET4 & 80.7356 & 256.664 & .694 & .934 \\
\hline ERE1 & 80.7175 & 258.282 & .693 & .934 \\
\hline ERE2 & 81.6390 & 264.779 & .629 & .935 \\
\hline ERE4 & 81.2447 & 257.719 & .768 & .932 \\
\hline ERE5 & 80.5514 & 261.606 & .702 & .934 \\
\hline ERS1 & 83.5423 & 271.492 & .519 & .937 \\
\hline ERS2 & 82.0151 & 259.652 & .757 & .933 \\
\hline ERS3 & 81.5574 & 264.643 & .767 & .933 \\
\hline ERS4 & 80.7492 & 266.058 & .607 & .935 \\
\hline EA1 & 80.8142 & 265.186 & .562 & .936 \\
\hline EA2 & 82.5211 & 273.161 & .483 & .937 \\
\hline EA3 & 81.0982 & 262.400 & .669 & .934 \\
\hline EA4 & 80.6964 & 265.806 & .654 & .935 \\
\hline EE1 & 83.3640 & 265.454 & .566 & .936 \\
\hline EE3 & 83.2779 & 267.768 & .546 & .936 \\
\hline EE4 & 81.9381 & 276.987 & .413 & .938 \\
\hline EE5 & 81.4305 & 273.628 & .579 & .936 \\
\hline \multicolumn{2}{|c|}{ Cronbach's Alpha } & $\mathrm{N}$ of Items & & \\
\hline \multicolumn{2}{|c|}{.895} & 5 & & \\
\hline aveET & 16,7032 & 10,917 & ,797 & ,855 \\
\hline aveERE & 16,6333 & 11,219 & ,748 & ,867 \\
\hline aveERS & 17,5612 & 12,036 & ,861 & 845 \\
\hline aveEA & 16,8776 & 12,423 & ,711 & 874 \\
\hline aveEE & 18,0978 & 13,438 & ,596 & ,894 \\
\hline
\end{tabular}


Apendix 2b. Cronbach's Alpha for service elements for perceptions.

\begin{tabular}{|c|c|c|c|c|}
\hline \multicolumn{2}{|c|}{$\begin{array}{c}\text { Cronbach's Alpha } \\
\mathbf{9 2 7}\end{array}$} & $\frac{\mathrm{N} \text { of Items }}{\mathbf{2 2}}$ & \multirow[b]{2}{*}{$\begin{array}{c}\text { Corrected Item- } \\
\text { Total } \\
\text { Correlation }\end{array}$} & \multirow[b]{2}{*}{$\begin{array}{c}\text { Cronbach's } \\
\text { Alpha if Item } \\
\text { Deleted }\end{array}$} \\
\hline & $\begin{array}{l}\text { Scale Mean if } \\
\text { Item Deleted }\end{array}$ & $\begin{array}{l}\text { Scale Variance } \\
\text { if Item Deleted }\end{array}$ & & \\
\hline PT1 & 84.2326 & 227.976 & .698 & .921 \\
\hline PT2 & 84.5634 & 235.012 & .613 & .923 \\
\hline PT3 & 84.2644 & 227.163 & .714 & .921 \\
\hline PT4 & 84.3671 & 225.552 & .694 & .921 \\
\hline PRE1 & 82.1193 & 238.977 & .549 & .924 \\
\hline PRE2 & 82.1631 & 243.743 & .315 & .927 \\
\hline PRE4 & 82.8142 & 235.846 & .566 & .924 \\
\hline PRE5 & 82.4592 & 235.020 & .612 & .923 \\
\hline PRS2 & 83.2009 & 228.778 & .745 & .920 \\
\hline PRS3 & 82.7553 & 235.852 & 679 & .922 \\
\hline PRS4 & 82.0514 & 246.618 & .314 & .927 \\
\hline PA1 & 83.9260 & 221.736 & .776 & .919 \\
\hline PA2 & 85.4048 & 230.489 & .678 & .922 \\
\hline PA3 & 85.6858 & 237.260 & .599 & .923 \\
\hline PA4 & 85.4592 & 229.861 & .704 & .921 \\
\hline PE1 & 84.7341 & 234.413 & .534 & .925 \\
\hline PE2 & 84.4909 & 228.774 & .736 & .920 \\
\hline PE3 & 83.2175 & 244.080 & .385 & .927 \\
\hline PE4 & 82.6798 & 243.144 & .500 & .925 \\
\hline PE5 & 82.8172 & 236.522 & .555 & .924 \\
\hline \multicolumn{2}{|c|}{ Cronbach's Alpha } & $\mathrm{N}$ of Items & & \\
\hline \multicolumn{2}{|r|}{.843} & 5 & & \\
\hline avePT & 18,5310 & 9,925 & ,621 &, 810 \\
\hline avePRE & 16,5631 & 11,692 & ,496 & ,838 \\
\hline avePRS & 16,8434 & 11,183 & 643 & ,799 \\
\hline avePA & 19,2931 & 9,900 & ,728 & ,773 \\
\hline avePE & 17,7621 & 11,369 & ,744 & ,781 \\
\hline
\end{tabular}




\title{
ПРОЦЕНА КВАЛИТЕТА УСЛУГА ВИСОКОГ ОБРАЗОВАЊА: ИНТЕГРАЦИЈА SERVQUАL МОДЕЛА И АНР МЕТОДА
}

\author{
Раденко Милојевић, Марија Радосављевић \\ Умниверзитет у Нишу, Економски факултет, Ниш, Србија
}

\section{Резиме}

Током процеса образовања људи стичу и развијају своја знања, али и своје компетенције, професионалне и социјалне вештине. Иако сви нивои образовања имају сврху и улогу у обезбеђивању развоја друштва, значај високог образовања у 21. веку се посебно повећао. У последњих неколико декада тржиште високог образовања захваћено је трендом глобализације. У земљама у развоју то значи да се факултети и универзитети суочавају са конкуренцијом. Да би задржали позицију, морају схватити да је квалитет услуге критичан услов за опстанак и раст на тржишту образовања.

Мерење квалитета услуга високошколских установа је важан задатак за обезбеђење повратних информација о елементима квалитета, те је у ту сврху SERVQUAL модел стекао велику популарност и широку примену последњих деценија. Према сазнањима аутора, истраживање на основу SERVQUAL модела до сада није спроведено у Србији.

Сврха истраживања представљеног у овом раду је да се истакне квалитет као извор конкурентске предности високошколских установа, као и да се идентификују могућности за побољшање квалитета услуга ових установа. Међутим, главни циљ истраживања је да се процени да ли квалитет услуга утиче на задовољство студената. Перцепција студената о квалитету услуга сматра се показатељем њиховог задовољства, а тиме и успеха високошколских установа у постизању и/или одржавању конкурентске предности на тржишту високог образовања.

Подаци који се користе у анализи прикупљени су стандардним упитником који се састоји од 22 ставке. Пошто су вредности Cronbach's Alpha веће од 0,70, поузданост прикупљених података сматра се прихватљивом. Подаци су били предмет анализе путем SERVQUAL модела. Овај модел је користан, али сигурно није довољан за креирање мапе побољшања. Стога је за идентификацију квалитета услуга, поред SERVQUAL модела, у анализи коришћен AHP метод, упарени т-тест, ANOVA и регресиона анализа.

Да би се добили што прецизнији резултати, за израчунавање укупног јаза коришћен је АНР метод, на основу кога су одређени одговарајући тежински коефицијенти. После израчунавања SERVQUAL јаза, закључено је да су Сигурност $(2,944656)$ и Опипљивост $(3,673664)$ елементи услуга са најнижим просечним вредностима.

Поузданост и Емпатија, као елементи који имају највеће тежинске коефицијенте, истовремено су и елементи са значајним позитивним јазом, тако да представљају светлу страну квалитета услуга високошколских установа. Коначно, значајна је чињеница да, на основу регресионе анализе, све ставке у оквиру ова два елемента квалитета услуге имају статистички значајан утицај на задовољство студената. 